\title{
AN ATTEMPT TO IMPROVE HATCHABILTY PERCENTAGE OF BRONZE TURKEY EGGS BY TECHNIQUE OF IN OVO INJECTION WITH L- CARNITINE
}

\author{
Ghonim, A. I. A.; Samya E. Ibrahim; Sh. M.Zayed and Hoda A. Gad \\ Anim. Prod. Res. Institute, Agric. Res. Center, Ministry of Agric. Dokki, Giza
}

Corresponding author: Ghonim, A. I. A Email: aymen_ghonim@yahoo.com Received: $25 / 01 / 2021$ Accepted: 24/02/2021

\begin{abstract}
This study aimed to investigate the effects of pre-incubation in ovo injection with different levels of L- carnitine (L-Car) on hatchability traits of Bronze Turkey eggs, blood plasma constituents and subsequent growth performance of hatched chicks. A total of 300 hatching eggs of Bronze Turkey were chosen (averaged $80.0 \mathrm{~g}$ ) and randomly divided into four main groups each of three replicates ( 25 eggs each). The $1^{\text {st }}$ group was used as a control (C) without injection, while the $2^{\text {nd }}, 3^{\text {rd }}$ and $4^{\text {th }}$ groups were injected with $0.1 \mathrm{ml}$ distilled water contained 6,8 or $10 \mathrm{mg}$ L-Car/egg, respectively. Hatchability (\%), Early and late embryonic mortality (\%) were calculated. After hatch, 33 chicks were taken from each treatment group then distributed into three replicates (11 chicks, each), then reared up to $\Lambda \leqslant$ d-old to evaluate their growth performance. The results indicated that, in- ovo L-car injection (with $6.0 \mathrm{mg} / \mathrm{egg}$ ) before incubation had significantly $(\mathrm{P} \leq 0.01)$ increased hatchability $(\%)$ of fertile eggs and decreased $(\mathrm{P} \leq 0.01)$ both early and late embryonic mortality compared with the control group (non-injected). Hatched chicks from injected eggs with $6.0 \mathrm{mg} \mathrm{L}$-car /egg recoded a significant $(\mathrm{P} \leq 0.01)$ improvement of all studied growth traits during the entire period after hatch as compared with the other treatment groups. Blood Plasma IGF-1, triiodothyronine and total antioxidant capacity constituents were significantly elevated for chicks at hatch by in ovo L-car injection compared to control group. Histological examination explained an improvement in small intestine and lymphoid organs development by in ovo L-car injection compared to the control group. So, we concluded the in ovo L-car injection $(6 \mathrm{mg} / \mathrm{egg})$ before incubation could be used as a promising technical method to improve hatchability and decrease embryonic mortality (\%), obtain better immunity and subsequent growth performance of Bronze turkey chicks after hatch.
\end{abstract}

Key words: L-carnitine, In ovo, performance, Hatchability, Bronze turkey. 


\section{INTRODUCTION}

Turkey eggs are mainly used to artificial incubation for turkey chick's production. Hatchability is an important economic trait of domestic poultry and represents a major component of reproductive fitness (Weis et al., 2011). Different factors play an important role on hatchability during embryogenesis and post- hatch performance such as genetic, incubation condition and egg quality traits (Abiola et al., 2008). The influence of L-carnitine (L-car) administration on hatchability and post-hatch performance has generated considerable interest in recent years. Lcarnitine $(\beta-\mathrm{OH}-\gamma-\mathrm{N}-$ trimethylaminobutyrate) is a water soluble quaternary amine that naturally occurs in microorganisms, plants and animals. It can be synthesized from lysine and methionine in animals. The L-car acts as an antioxidant that ultimately results in a decrease in reactive oxygen species (ROS) by removing excessive levels of intracellular acetyl CoA, which induces mitochondrial (ROS) production. Therefore, it may work as an antioxidant to scavenge free radicals (Agarwal et al., 2005). Also, L-car transports long chain fatty acids across mitochondrial membranes for $\beta$-oxidation of fatty acids for energy production. In such situations, exogenous supplementation of L-car could prove advantageous (Buyse et al., 2001), and could in turn be used by the chick during hatching. In ovo feeding of supplemental nutrients may help to overcome the constraint of limited egg nutrients (Foye et al., 2006), and may provide poultry companies with an alternative method to increase hatchability and weight of newly- hatched chick (Ohta et al., 2001).
The injection of amino acid mixture into growing embryos in broiler breeder eggs resulted in high body weight at hatch and at $56 \mathrm{~d}$ of age compared with chick from control embryos (Ohta et al., 1999). It was also documented that chicken embryos have a limited capacity to synthesize L-Car during incubation due to the low activity of the enzme $\gamma$ butyrobetaine hydroxlase, which is essential for L-Car biosynthesis (Borum, 1983; Rebouche, 1992). Thus, the injection of L-Car in the fertile egg may decrease embryonic mortality by reducing oxidative stress during the hatch process, thereby increasing hatch rate. Salmanzadeh et al. (2013) found that injection of L-Car into eggs of turkey breeder hens at the $6^{\text {th }}$ day of incubation caused a significant depression in hatchability percentage, and reported that, reduction in hatchability may be related to the solution injection into yolk sac has created a cavity that may interfere with embryo respiration leading to the embryo death and decreasing hatchability. AlMurrani (1978) suggested that differences in protein content of eggs at day's 0 and 7 of incubation could affect the growth of embryos. Several studies illustrated that, fortification of fertile eggs with different nutrients, i.e. vitamins, L-carnitine (LCar) before incubation was reported as promised tool to improve carcass quality by increasing lean to fat percentage and enhance different performance traits of broilers ( Abdel-Fattah et al., 2014 and Mast and Goddeeris, 2000). Al-Daraji et al. (2012) reported that, the in ovo injection of L-arginine at 0 day of incubation could be used as an efficient tool to improve the productive performance of Japanese quail. Also, Ghonim (2016) reported that in ovo- 
L-carnitine, In ovo, performance, Hatchability, Bronze turkey.

injection at pre- incubation with 6 or 8 $\mathrm{mg}$ L- car/egg improved hatchability traits and subsequent growth performance of Domyati ducks. The turkey produce low egg during laying season and it's high price so it's used for artificial incubation. Therefore, to avoid the problem of injection site (amnion or yolk sac) which lead to embryos death and decrease hatchability and to maximize the utilization of the turkey egg production, thus, this study aimed to investigate the effect of in ovo injection of Bronze turkey eggs with different level of L-Car at pre- incubation on hatchability traits, some blood plasma constituents of turkey chicks and subsequent growth performance of turkey poults.

\section{MATERIALS AND METHODS}

This study was carried out at Mahallet Moussa-Turkey Research Station, Animal Production Research Institute, Agriculture Research Center, Ministry of Agriculture, Egypt.

In ovo injection and Hatching: A total of 300 Bronzy Turkey eggs (averaged $80.0 \mathrm{~g}$ ) were obtained from Turkey breeder flock, then were randomly divided in four groups each of three replicates (25 eggs, each). The first group served as a control (C, without injection), while the second, third and fourth groups eggs were punctured in the large end to make a hole by hard and thin stylus and this area was disinfected by using ethyl alcohol and injected with $0.1 \mathrm{ml}$ of distilled water contained 6,8 and $10 \mathrm{mg}$ L-Car respectively in the air cell by using graded syringe $(1 \mathrm{ml})$, then, sealed using nontoxic glue. L- Car hydrochloride $98 \%$ purity was used. All eggs were incubated at $99.5{ }^{\circ} \mathrm{F}$ and $60 \%$ relative humidity ( $\mathrm{RH})$ in an automatic incubator. At day 25 of incubation all eggs were transferred to the hatcher to complete the hatching process for 3 days at $99.0^{\circ} \mathrm{F}$ and $75 \% \mathrm{RH}$. At the $10^{\text {th }}$ day of incubation, eggs were candled to count fertile eggs number and estimate early embryonic mortality (\%). Then, after complete hatching, live hatched chicks, un-hatched eggs and dead chicks were counted to determine hatchability and late embryonic mortality $(\%)$.

After hatch, all hatched chicks were individually weighted, then 33 hatched chicks belonging to each experimental group were taken and divided into three replicates (11 chicks each). Turkey chicks were reared under similar environmental and managerial conditions. They were fed on commercial diets. The composition and calculated analysis of the experimental diets are shown in Table 1 .

Blood metabolite: At hatching, individual blood samples were withdrawn from 5 chicks within each treatment in heparinized test tubes; before blood centrifuged, a part of blood sample was used for estimate blood hematology concentration. Hemoglobin concentration $(\mathrm{Hgb})$ was determined of fresh samples using hemoglobin meters as method described by (Tietz, 1986). Red blood cells counts (RBC's), MCV , MCHC and Hematocrite (\%) were detected according to the method of (Helper (1966). After then the second part of blood was centrifuged at $3500 \mathrm{rpm}$ for 15 minutes to get blood plasma. Plasma samples were stored at $-20{ }^{\circ} \mathrm{C}$ until analysis to determine total protein (Gornal et al., 1949) and albumin (Doumas, et al., 1971) by using commercial kits. However, globulin was obtained by subtraction of plasma albumin from total protein. The radioimmunoassay (RIA) method was used for the determination of triiodothyronine (T3 $\mathrm{ng} / \mathrm{dl}$ ) using 
Ghonim, A. I. A.et al.

commercial kits according to Britton et al. (1975); insulin like growth factor-1 (IGF-1), using commercial RIA kits. Total antioxidant capacity (TAC $\mathrm{mmol} / \mathrm{ml}$ ) according to Koracevic et al. (2001).

Histological observations: Representative tissue specimens from duodenum, bursa of Fabricius, thymus, and spleen were carefully dissected from chicks at hatch. They were fixed in a $10 \%$ formalin-Saline solution before applying the paraffin method technique. Specimens were dehydrated in ascending grades of ethyl alcohol; cleared in Zylol and then embedded in paraffin wax. Transverse sections (4-5 microns, thickness) were taken, mounted on glass slides and stained with Hematoxylin and Eosin stains $(\mathrm{H} \& \mathrm{E})$. All sections were examined under electric microscope provided with a computerized camera.

Growth parameters: Live body weight (LBW) of Turkey chicks were recorded at hatch, 28, 56 and 84 day of age. The body weight gain (BWG), feed consumption (FC), and feed conversion ratio (FCR) were calculated through the periods of 1 $28,29-56,57-84$ and 1-84 day of age.

Statistical analysis: Data were subjected to one - way analysis of variance using general linear model (GLM) procedure of SAS program (SAS, 2004) based on the following model: $\quad \mathrm{Yij}=\mu+\mathrm{T}+$ eij where, $Y i j=$ An observation, $\mu=$ Overall mean, $\mathrm{Ti}=$ Effect of treatment $(1,2, \ldots \ldots$, 4), and eij = Random error. All percentage data were subjected to arcsine transformation of the square root before statistically reanalyzed however, the actual percentage means are presented. Significant differences among treatments means were tested by Duncan's multiple range test (Duncan, 1955) at a probability level of 0.05 .

\section{RESULTS AND DISCUSSION Hatching traits:}

Results of Table 2 shows the effect of pre- incubation in ovo L- Car injection on hatching traits of Bronze Turkey eggs. Eggs injected with $6.0 \mathrm{mg}$ L- car/egg recorded $(\mathrm{p} \leq 0.01)$ improvement of hatchability (\%) by about 4.26 and 6.13 $\%$ on the basis of set and fertile eggs, respectively as compared to control group. While, injected eggs with $10.0 \mathrm{mg}$ L- car / egg had significantly lower hatchability of both set and fertile eggs compared with those injected with 6.0 or $8.0 \mathrm{mg} \mathrm{L}$. car/egg and the control group. Generally, the best hatchability percentage occurred by L-car injection with 6.0 followed $8.0 \mathrm{mg} / \mathrm{egg}$ before incubation as a result of the decrease in early and late embryonic mortality. The improvement of hatchability (\%) and decreasing of early and late embryonic mortality may be due to the role of L-Car in the increase of ATP release from fatty acid catabolism, which could use by chick to facilitate hatching. Furthermore, it may work as antioxidant by scavenging free radicals, hence, reduces the incidence of late dead embryos (Zhai et al., 2008). Our results are in close agreement with those reported by Abd El- Azeem e al., 2014 and Abdel- Fattah and shourrap, 2012 and Ghonim, 2016. However, Dooley et al., 2011; Zhai et al., 2008; Keralapurath et al., 2010 and Shafey et al., 2010, found no effect of L- Car on hatchability percentage. Also, Salmanzadeh et al., 2013, reported that, in ovo injection of L- Car (10, 20 or $30 \mathrm{mg}$ ) at day 6 of incubation of turkey breeder eggs caused a significant decrease of hatchability. On the other hand, it is notice from the results that, injected eggs with different L-car levels resulted in increase of turkey chick's weight at hatch 
L-carnitine, In ovo, performance, Hatchability, Bronze turkey.

with or without significant effect. Chicks hatched from injected eggs with $10 \mathrm{mg} \mathrm{L}$ car/eggs had heavier $(\mathrm{p} \leq 0.01)$ body weight at hatch than non-injected eggs, only.

\section{Blood constituents at hatch:}

In-ovo injection with L-car in Bronze turkeys eggs at pre-incubation revealed a significant $(\mathrm{p} \leq 0.01)$ effects on all blood plasma constituents, while all studied blood hematology parameters not significantly affected for chicks at hatch (Table 3). The noticeable observation is that the eggs injected with 8 and $10 \mathrm{mg}$ L- car/egg resulted in chicks that obviously higher values of plasma total protein, albumin, and globulin concentration compared to the control and those injected with $6.0 \mathrm{mg} / \mathrm{egg}$ group. In contrast, Ghonim (2016) indicated that, no significant differences were observed between ducklings produced from eggs injected with L-car and control groups. This different according L-car doses and the species of experimental birds. On the other hand, resulted showed that, chicks hatched from eggs injected with $10 \mathrm{mg} \mathrm{L-}$ car/egg had $(\mathrm{P} \leq 0.01)$ higher values of IGF1, T3 and TAC followed by 8 and 6 mg L- car/ egg groups compared to control group. This may explain that, the important role of L-car as an antioxidant agent that protect living cell membrane damage, hence increased synthesis of IGF-1 and T3 hormones and has as a sparing effect for methionine and lysine to further protein synthesis. Our results are in close agreement with those of Ghonim (2016) who reported that the groups injected with10, 20 and $30 \mathrm{mg} \mathrm{L-}$ car/egg resulted in significantly higher values of IGF-1 and T3 hormones concentration in blood plasma compared to control groups of Domyati Ducks. Also, Abd El- Azeem, et al. (2014) fond that, in ovo injection with L- car or folic acid significantly increased IGF-1 and T3 hormones of broiler chickens.

\section{Histological observation:}

Histological examination of the small intestine sections from one day old turkey chicks showed interesting results (Fig. 1 to 4). It is clear that the sections obtained from the developmental pattern of the small intestine of chicks hatched from inovo injected_eggs with L-car were enhanced compared to those of the control group. There are many well developed villi and crypts in chicks hatched_from L- car treated groups, especially those injected with $6.0 \mathrm{mg}$ (Fig. 2) followed by $10 \mathrm{mg} \mathrm{L}$ - car (Fig. 4) group. Moreover, the thickness of muscular mucosa (MM) layer was greater in all sections except for chicks obtained from the $8 \mathrm{mg}$ in ovo- injected eggs (Fig. $3)$. However, the latter section showed a standard arrangement of the intestinal villi, although the observed decrease in size and number of crypts of lieberkuhn. These crypts are known to secrete watery fluids containing different vital substances essential for the internal micro- environment of different small intestine segments (Hodges, 1974). Moreover, the presence of many goblet cells in the epithelial lining of the crypts was reported to be responsible for secretion of some solutions that reduce the $\mathrm{PH}$ value of the small intestinal parts, allowing more digestive enzymes activity, hence better nutrients digestion and absorption (Abd El- Moneim, et al., 2020). The previous observations may be related to the role of $\mathrm{L}$ - car that increase the level of the IGF-1 and $\mathrm{T}_{3}$ hormones during embryogenesis as recorded in the blood parameters Table- 3. This is close agreement with the results of Abd ElAzeem, et al., (2014) who reported that in 
Ghonim, A. I. A.et al.

ovo injection of L- car or folic acid significantly increased IGf-1 and $\mathrm{T}_{3}$ hormones of broiler chickens.

\section{Lymphoid organs histology:}

The effect of in ovo injection of turkey eggs with different L-car doses on the histological structure of Bursa Fabricius and thymus gland at one-day old of hatched chicks is illustrated in Fig. 5- 12. It is well known that the Bursa is a primary lymphoid organ in birds. In general, it is composed of about 15- 20 plicae (folds), each of them contain numerous follicles. These follicles have two distinct are as: cortex and medulla (Hodges, 1974). Our results showed similar arrangement of both cortex and medullary areas as clearly observed in Fig. 5 to 8 with minor changes due to Lcar treatments. In all section, the cortex area is more deeply- stained than the medullary one, due mainly to the fact that it composed of many small lymphocytes. The medullary area is composed of many un- differential cells along with large lymphocytes which appeared as pale stained area. These histological observations are clearly shown in the control sections (Fig. 5), however, in the L-car groups, the number and size of bursal follicles, being greater than the control one. It is likely that L-car injection into eggs, may exacerbate the growth of bursa follicle, which means better humoral immunity. This holds true, as bursa is the source of B-lymphocytes and antibody production. The best section was occurred in chicks hatched from injected eggs with $10 \mathrm{mg} \mathrm{L}$-car /egg.

Also, the histological overview of thymus sections from different in ovo and control groups showed the general structure of the gland, it is composed of many thymic lobules which differ in their size and shape. These lobules are in closed by a thin connective tissue capsule, while many fine septae that divide the gland to several lobules. It is evident from section that both sections from the control (Fig.9) and $8 \mathrm{mg} \mathrm{L}$-car- injection (Fig.11) groups showed little response to L-car in ovo injection, However, the other groups responses greatly to L-car in terms of well- organized cortex and medullary area and the presence of fine septae in between many enlarged thymes lobules (Fig. 10, 12). This trend of growth pattern of thymus may be related to the previously observed improvement of bursa histology. In this concern, Akter et al. (2006) and Khan et al. (2014) reported that the immune response of chicks at early ages depends mainly on Blymphocytes production (Bursal- origin) than T- lymphocytes from thymus gland. This was also supported by the findings from El-Daly et al. (2014) which in close agreement of our results.

\section{Spleen histology:}

The histological structure of the spleen as influenced by different in ovo L-car injection treatments is illustrated in Fig. 13- 16. It is clear from these sections that the basic structure of spleen from different treatments has nearly similar architecture, in which two main areas could be seen, i. e. a large white pulp (WP) area and a dark- stained red pulp (RP) one with numerous blood capillaries, sinusoids, and many lymphocytes and few lymphatic nodules. These were an irregular distribution of the RP area within the white pulp, with more $\mathrm{RP}$ regions intermingled in the WP area, as observed in Fig. 14 and 16. The extended RP area all over the spleen sections from 6 or $10 \mathrm{mg}$ L-car treatments with the marked increase in the number of large lymphocytes accompanied by hemosiderin- basophile granules that may 
L-carnitine, In ovo, performance, Hatchability, Bronze turkey.

reflect an improvement in immune response of chicks from these treatment groups. In this respect, spleen is considered as a secondary lymphoid organ in birds, and it was reported as the main site of lymphocytes proliferation and differentiation (Hodges, 1974). Thus, there is evidence that spleen of birds harbors large numbers of T- cells and Bcells which differentiate into antigenspecific effector cells. This confirms our results and could be considered as an early indication for the expected enhancement in immunity of turkey chicks at older ages via $\mathrm{L}-$ car in ovo injection during embryogenesis.

Productive performance of hatched chicks:

Results presented in Table 4, showed significant effects of the pre-incubation injection of Bronze Turkey eggs with Lcar on post-hatch growth performance of Turkey chicks. It is clearly noticed from the present results that, pre-incubation in ovo eggs injection with L-Car was improved $(\mathrm{P} \leq 0.01)$ subsequent live body weight (LBW) of Bronze Turkey chicks at different ages after hatch up to 84 day of age. The heavier chicks LBW at hatch produced from injected eggs with $10 \mathrm{mg}$ L-car/egg. Moreover, LBW of chicks produced from eggs injected with different L-car levels improved at 56 and 84 d-old after hatch with or without significant effect compared to control group. Eggs injected with $6 \mathrm{mg} \mathrm{L-}$ car/egg obtained chicks that higher LBW at different studied ages except for at hatch compared to the other treatment groups. The increase LBW may be due to the increase in myogenesis process during incubation as a result of L-Car injection. Also, an increase in efficiency of fatty acids oxidation which subsequently led to an improved utilization of dietary nitrogen thereafter. Our results are in close agreement with Ghonim (2016), Rabie et al. (2015), and Abd El-Azeem et al. (2014). However, Zhai et al. (2008) reported that, in ovo injection with L-Car into fertile eggs at 17 or $18 \mathrm{~d}$ of incubation did not effect on LBW. Moreover, Keralapurath (2010) stated that, no significant effects of L-Car doses $(0.5,2.0,8 \mathrm{mg})$ injected in fertilized eggs at the $18^{\text {th }}$ day of incubation on growth performance of white Leghorn. These differences are due mainly to the different time injection and dose of L-Car and also to the bird species.

On the other hand, body weight gain (BWG) data in Table 4, revealed that chicks BWG was significantly $(\mathrm{P} \leq 0.01)$ improved for hatched chicks from eggs injected with $6 \mathrm{mg}$ L-Car/egg during the period of 1-28, 29-56 and the whole experimental period (1-84 day of age) as compared to the other treatment groups. These results are in agreement with Ghonim (2016) Abdel-Fattah and shourrap, (2012) and Salmanzadeh et al. (2012). However, Keralapurath et al. (2010) reported that, no significant effects of L-Car injection on weight gain.

Concerning the effect of in ovo injection with L.car at pre incubation on subsequent chicks feed consumption after hatch, it could be noticed that chicks hatched from eggs injected with $6 \mathrm{mg} \mathrm{L}$ car/egg had consumed $(\mathrm{P} \leq 0.01)$ more feed amount than the other treatment groups at 1-28 days of age, meanwhile, the group injected with $10 \mathrm{mg}$ L.car/egg recorded the lower $(\mathrm{P} \leq 0.01)$ amount of feed than the other treatment groups at periods of 1-28, 29-56 and 1-84 days of age compared to the other treatment groups. It is clearly from these results, in ovo L-Car injection with the different doses gave chicks had lower FC amount 
Ghonim, A. I. A.et al.

as compared to the_control group during the entire period of experiment after hatch. These results are in close agreement with those of Ghonim (2016) on ducks, Rabie et al. (2015) on broiler and Salmanzadeh et al. (2013) on turkey breeder strain.

Moreover, feed conversion ratio ( $\mathrm{g}$ feed/g gain) was significantly affected by in ovo -injection with L.car during all the experimental periods (Table 4). The better FCR was recorded for all chicks produced from injected eggs with different L-car doses in comparison with non-injected group during the entire period after hatch, while, the best group that obtained from L-car injection with $6.0 \mathrm{mg} / \mathrm{egg}$ than other groups. This improvement in FCR may be due to the improvement final LBW and cumulative BWG and low feed consumption. These results are in close agreement with Ghonim (2016), Rabie et al.)2015), Abed El-Azeem et al. (2014), Abdel-Fattah and shourrap (2012) and Salmanzadeh et al.(2012).

\section{CONCLUSION}

From the previous results, it could be concluded the in ovo injection method with L-car (6 mg/egg) could use as beneficial technical before incubation to improve hatchability and decrease embryonic mortality (\%), better immunity and growth performance of Bronze turkey chicks after hatch.

Table(1): Composition and calculated analysis of the basal diets.

\begin{tabular}{|c|c|c|c|}
\hline \multirow{2}{*}{ Ingredients \% } & \multirow{2}{*}{$\begin{array}{l}\text { Starter } \\
1-28 \text { day }\end{array}$} & \multicolumn{2}{|c|}{ Grower } \\
\hline & & 29-56day & $57-84$ day \\
\hline White Corn & 47.0 & 55.0 & 58.0 \\
\hline Soybean meal (44 \%) & 17.0 & 14.0 & 12.0 \\
\hline Broiler concentration & 22.0 & 18.0 & 15.0 \\
\hline Fish meal $(60 \%)$ & 8.5 & 7.0 & 8.0 \\
\hline Soybean oil & 2.5 & 2.5 & 3.5 \\
\hline Limestone & 0.5 & 1.0 & 1.0 \\
\hline Bone meal & 1.5 & 1.5 & 1.5 \\
\hline Salt $(\mathrm{NaCl})$ & 0.5 & 0.5 & 0.5 \\
\hline Vit. And Mimeral premix* & 0.5 & 0.5 & 0.5 \\
\hline Total & 100 & 100 & 100 \\
\hline \multicolumn{4}{|l|}{ Calculated Analysis } \\
\hline Crude protein $\%$ & 27.7 & 24.2 & 18.5 \\
\hline ME ( Kcal / kg ) & 2809.6 & 2858.7 & 2947.5 \\
\hline Calorie : Protein ratio & 101.4 & 118.1 & 131.0 \\
\hline
\end{tabular}

1- Each $3 \mathrm{~kg}$ of the Vit and Min. contains: Vitamin A 10 MIU, Vit. D 2 MIU, Vit E $10 \mathrm{~g}$, Vit. K 2 g, Thiamin 1 g, Riboflavin 5 g, Pyridoxine 1.5 g, Niacin 30 g, Vit. B12 10 mg, Pantothenic acid $10 \mathrm{~g}$, Folic acid $1.5 \mathrm{~g}$, Biotin $50 \mathrm{mg}$, Choline chloride $250 \mathrm{~g}$, Manganese 60 g, Zinc 50 g, Iron 30 g, Copper $10 \mathrm{~g}$, Iodine $1 \mathrm{~g}$, Selenium $0.10 \mathrm{~g}$, Cobalt $0.10 \mathrm{~g}$. and carrier $\mathrm{CaCO} 3$ to $3000 \mathrm{~g}$. 
L-carnitine, In ovo, performance, Hatchability, Bronze turkey.

Table (2): Effect of in ovo injection of Bronze turkey eggs with L-Carnitine (L- Car) at pre- incubation period on hatching traits.

\begin{tabular}{|c|c|c|c|c|c|c|}
\hline \multirow{2}{*}{ Traits (\%) } & \multicolumn{4}{|c|}{ Treatments } & \multirow{2}{*}{ SEM } & \multirow{2}{*}{ Sig. } \\
\cline { 2 - 5 } & \multirow{3}{*}{$\begin{array}{c}\text { Control } \\
\text { (Non-injected) }\end{array}$} & $\mathbf{6 . 0}$ & $\mathbf{8 . 0}$ & $\mathbf{1 0 . 0}$ & & \\
\cline { 2 - 6 } & $78.33^{\mathrm{b}}$ & $81.67^{\mathrm{a}}$ & $78.33^{\mathrm{b}}$ & $75.00^{\mathrm{c}}$ & 0.45 & $* *$ \\
Hatchability of set eggs & $82.46^{\mathrm{b}}$ & $87.52^{\mathrm{a}}$ & $83.92^{\mathrm{b}}$ & $80.41^{\mathrm{c}}$ & 0.31 & $* *$ \\
Hatchability of fertile eggs & $7.02^{\mathrm{b}}$ & $5.36^{\mathrm{c}}$ & $7.11^{\mathrm{b}}$ & $8.97^{\mathrm{a}}$ & 0.26 & $* *$ \\
E.E.M & $10.53^{\mathrm{a}}$ & $7.12^{\mathrm{b}}$ & $8.96^{\mathrm{ab}}$ & $10.62^{\mathrm{a}}$ & 0.30 & $* *$ \\
LEM & $53.13^{\mathrm{b}}$ & $54.27^{\mathrm{ab}}$ & $54.07^{\mathrm{ab}}$ & $55.1^{\mathrm{a}}$ & 0.37 & $* *$ \\
\hline Chick weight $(\mathrm{g})$ & & & &
\end{tabular}

E. E. M \& L. E. M.= early and late embryonic mortality; SEM= pooled standard error mean; $* *=$ High significant; Sig. Significance.

a,b,c...means within row with different superscripts are significantly different $(\mathrm{P} \leq 0.01)$.

Table 3: Effect of in ovo injection with L-Carnitine (L-Car) on blood plasma constituents of Bronze Turkey chick at hatching.

\begin{tabular}{|c|c|c|c|c|c|c|}
\hline \multirow[b]{3}{*}{ Traits } & \multicolumn{6}{|c|}{ Treatments } \\
\hline & \multirow{2}{*}{$\begin{array}{c}\text { Control } \\
\text { (Non- } \\
\text { injected) }\end{array}$} & \multicolumn{3}{|c|}{ L -Car doses/_one egg } & \multirow[b]{2}{*}{ SEM } & \multirow[b]{2}{*}{ Sig. } \\
\hline & & $6 \mathrm{mg}$ & $8 \mathrm{mg}$ & $10 \mathrm{mg}$ & & \\
\hline Total protein, $(\mathrm{g} / \mathrm{dl})$ & $3.9^{\mathrm{b}}$ & $4.71^{\mathrm{b}}$ & $5.49^{\mathrm{a}}$ & $5.99^{\mathrm{a}}$ & 0.24 & $* *$ \\
\hline Albumin (g/dl) & $2.35^{\mathrm{c}}$ & $2.65 b^{c}$ & $3.04^{\mathrm{ab}}$ & $3.17^{\mathrm{a}}$ & 0.14 & $* *$ \\
\hline Globulin (g/dl) & $1.58^{\mathrm{d}}$ & $2.06^{\mathrm{c}}$ & $2.45^{\mathrm{b}}$ & $2.82^{\mathrm{a}}$ & 0.11 & $* *$ \\
\hline $\mathrm{A} / \mathrm{G}$ ratio & $1.5^{\mathrm{a}}$ & $1.4^{\mathrm{ab}}$ & $1.3^{\mathrm{ab}}$ & $1.2^{\mathrm{b}}$ & 0.07 & $* *$ \\
\hline $\mathrm{IGF}-1(\mathrm{ng} / \mathrm{ml})$ & $57.66^{\mathrm{c}}$ & $74.61^{\mathrm{b}}$ & $77.87^{\mathrm{b}}$ & $90.33^{\mathrm{a}}$ & 1.43 & $* *$ \\
\hline $\mathrm{T}_{3}(\mathrm{ng} / \mathrm{ml})$ & $4.34^{c}$ & $5.3^{\mathrm{b}}$ & $5.98^{\mathrm{ab}}$ & $6.53^{\mathrm{a}}$ & 0.29 & $* *$ \\
\hline $\mathrm{TAC}(\mathrm{mmol} / \mathrm{ml})$ & $1.07^{\mathrm{c}}$ & $1.4^{\mathrm{b}}$ & $1.58^{\mathrm{ab}}$ & $1.77^{\mathrm{a}}$ & 0.07 & $* *$ \\
\hline \multicolumn{7}{|l|}{ Hematology } \\
\hline RBC's $\times 10^{6}$ & 3.44 & 3.8 & 3.86 & 3.72 & 0.17 & NS \\
\hline Hematocrit (\%) & 31.0 & 33.67 & 32.0 & 33.33 & 1.21 & NS \\
\hline Hemoglobin $(\mathrm{g} / \mathrm{dl})$ & 10.19 & 11.44 & 11.11 & 11.08 & 0.47 & NS \\
\hline $\operatorname{MCV}\left(\mu \mathrm{m}^{3}\right)$ & 90.13 & 88.98 & 82.76 & 89.69 & 3.37 & NS \\
\hline $\mathrm{MCHC}(\mathrm{g} / \mathrm{dl})$ & 32.92 & 33.95 & 35.21 & 33.29 & 2.28 & NS \\
\hline
\end{tabular}

$\mathrm{SEM}=$ standard error mean; $\mathrm{Sig}=$ significance $; \mathrm{T}_{3}=$ triiodothryonine; $\mathrm{TAC}=$ total antioxidant capacity; NS $=$ Non significant $* *=$ High significant; IGF-1= Insulin- like growth factors; RBC's = Red blood cells count; $\mathrm{MCV}=$ Mean Corpuscular Volume; $\mathrm{MCHC}=$ Mean Corpuscular Hemoglobin Concentration.

a,b,c...means within row with different superscripts are significantly different $(\mathrm{P} \leq 0.01)$. 
Ghonim, A. I. A.et al.

Table (4): Effect of in ovo injection with L- Carnitine (L-Car) at pre- incubation on subsequent growth traits for hatched chicks.

\begin{tabular}{|c|c|c|c|c|c|c|}
\hline \multirow{3}{*}{$\begin{array}{l}\text { Age } \\
\text { (day) }\end{array}$} & \multicolumn{4}{|c|}{ Treatments } & \multirow[b]{3}{*}{ SEM } & \multirow[b]{3}{*}{ Sig. } \\
\hline & \multirow{2}{*}{$\begin{array}{c}\text { Control } \\
\text { (Non- } \\
\text { injected) }\end{array}$} & \multicolumn{3}{|c|}{ L-Car doses/ one egg } & & \\
\hline & & $6 \mathrm{mg}$ & $8 \mathrm{mg}$ & $10 \mathrm{mg}$ & & \\
\hline \multicolumn{7}{|c|}{ Live body weight(g/ Turkey poults) at } \\
\hline Hatch & $53.13^{\mathrm{b}}$ & $54.27^{b}$ & $54.07^{b}$ & $55.43^{\mathrm{a}}$ & 0.4 & ** \\
\hline 28 day & $348^{\mathrm{b}}$ & $381.7^{\mathrm{a}}$ & $344.7^{\mathrm{b}}$ & $350^{\mathrm{b}}$ & 2.3 & ** \\
\hline 56 day & $1671.7^{\mathrm{c}}$ & $1785^{\mathrm{a}}$ & $1700^{\mathrm{b}}$ & $1696.7^{\mathrm{b}}$ & 6.6 & $* *$ \\
\hline 84 day & $3831.7^{\mathrm{b}}$ & $3983.3^{\mathrm{a}}$ & $3867.3^{\mathrm{b}}$ & $3883.3^{\mathrm{b}}$ & 16.7 & $* *$ \\
\hline \multicolumn{7}{|c|}{ Body weight gain (g/Turkey poults/28 day) } \\
\hline $1-28$ & $294.9^{\mathrm{b}}$ & $327.4^{\mathrm{a}}$ & $290.6^{\mathrm{b}}$ & $294.9^{b}$ & 2.12 & $* *$ \\
\hline $29-56$ & $1323.7^{\mathrm{c}}$ & $1403.3^{\mathrm{a}}$ & $1355.3^{\mathrm{b}}$ & $1346.3^{\mathrm{bc}}$ & 7.5 & $* *$ \\
\hline $57-84$ & 2161.3 & 2198.3 & 2167.3 & 2186.7 & 18.4 & NS \\
\hline $1-84$ & $3779.9^{\mathrm{b}}$ & $3929.1^{\mathrm{a}}$ & $3813.3^{\mathrm{b}}$ & $3827.9^{b}$ & 16.3 & $* *$ \\
\hline \multicolumn{7}{|c|}{ Feed consumption (g/Turkey poults/28day) } \\
\hline $1-28$ & $660^{\mathrm{b}}$ & $677.7^{\mathrm{a}}$ & $654^{\mathrm{b}}$ & $572^{\mathrm{c}}$ & 2.2 & $* *$ \\
\hline $29-56$ & $3250^{\mathrm{a}}$ & $3280.7^{\mathrm{a}}$ & $3258.3^{\mathrm{a}}$ & $3143.3^{\mathrm{b}}$ & 11.6 & $* *$ \\
\hline $57-84$ & $6829.3^{\mathrm{a}}$ & $6473.3^{c}$ & $6491.3^{c}$ & $655^{\cdot b}$ & 13.5 & $* *$ \\
\hline $1-84$ & $10739.3^{\mathrm{a}}$ & $10431.7^{b}$ & $10403.7^{\mathrm{b}}$ & $10263.3^{\mathrm{c}}$ & 20.2 & $* *$ \\
\hline \multicolumn{7}{|c|}{ Feed conversion ratio (g. feed/g. gain) } \\
\hline $1-28$ & $2.24^{\mathrm{a}}$ & $2.07^{b}$ & $2.25^{\mathrm{a}}$ & $1.95^{\mathrm{c}}$ & 0.02 & $* *$ \\
\hline $29-56$ & $2.46^{\mathrm{a}}$ & $2.34^{\mathrm{b}}$ & $2.41^{\mathrm{a}}$ & $2.33^{\mathrm{b}}$ & 0.02 & $* *$ \\
\hline $57-84$ & $3.16^{\mathrm{a}}$ & $2.96^{\mathrm{b}}$ & $3.0^{\mathrm{b}}$ & $3.01^{\mathrm{b}}$ & 0.02 & $* *$ \\
\hline $1-84$ & $2.84^{\mathrm{a}}$ & $2.66^{\mathrm{c}}$ & $2.73^{b}$ & $2.7 \cdot b$ & 0.02 & $* *$ \\
\hline
\end{tabular}

a,b,c...means within row with different superscripts are significantly different $(\mathrm{P} \leq 0.01)$.

Sig.= significance, $* *=$ High significant, NS= Non- significant. 
L-carnitine, In ovo, performance, Hatchability, Bronze turkey.

Transverse sections (T.S) in the intestine and bursa Fabricius for hatched chicks at hatch

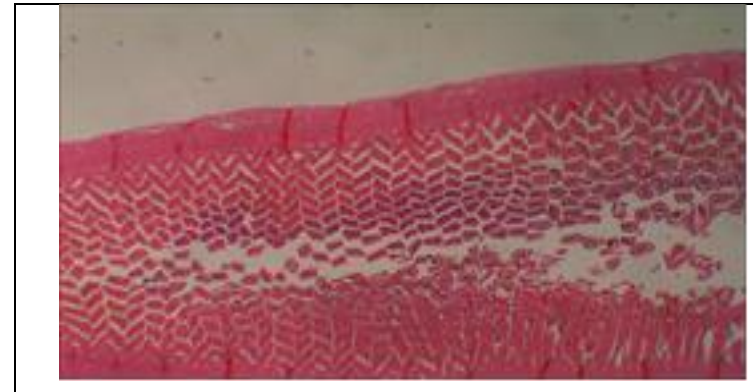

Fig. 1: in the intestine for chick in control group (H\&Ex 40).

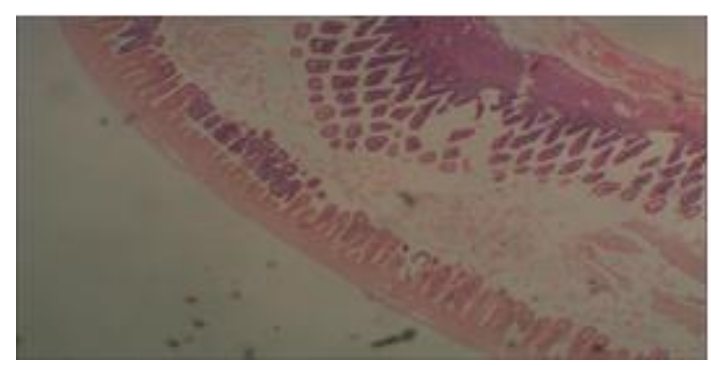

Fig. 3: in the intestine for chick in $8 \mathrm{mg}$ L-car injection group (H\&Ex 40).

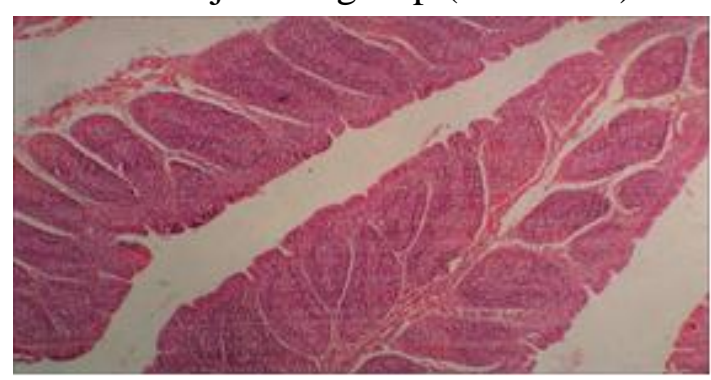

Fig. 5. T. S. in the bursa fabreceius for chick in control group (H\&Ex 40).

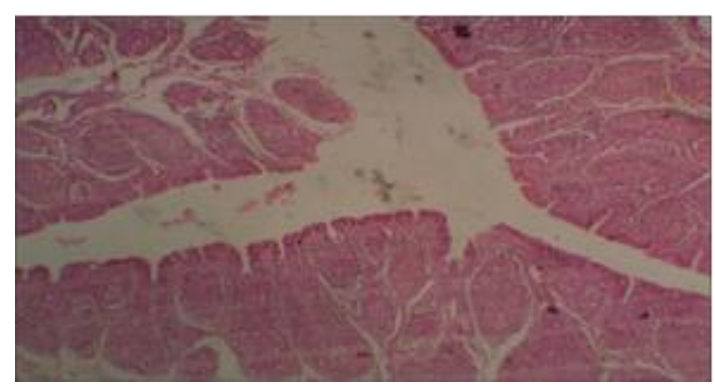

Fig. 7:T. S. in bursa fabriceius for chick in $8 \mathrm{mg} \mathrm{L}$-car injection group.

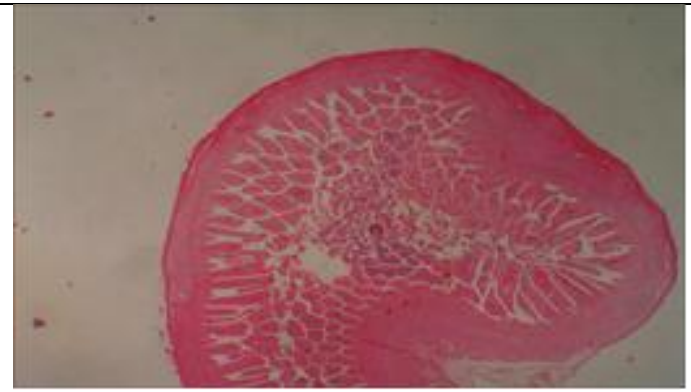

Fig. 2: in the intestine for chick in 6 mg L-car injection group (H\&Ex 40).

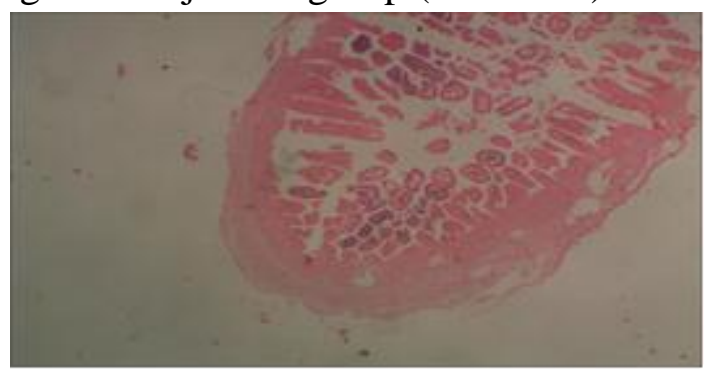

Fig. 4: in the intestine for chick in 10 mg L-car injection group (H\&Ex 40).

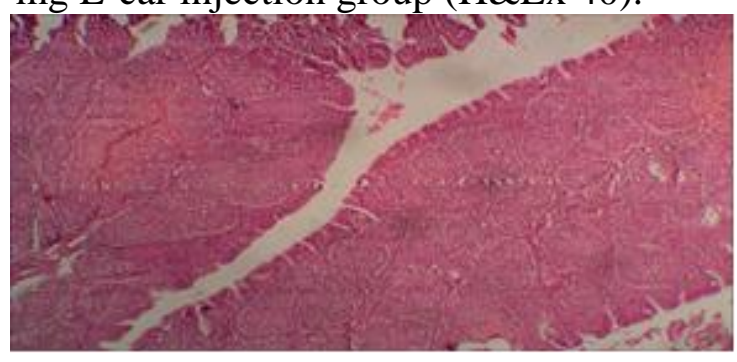

Fig. 6. T. S. in the bursa fabreiecuos for chick in $6 \mathrm{mg}$ L-car injection group (H\&Ex 40).

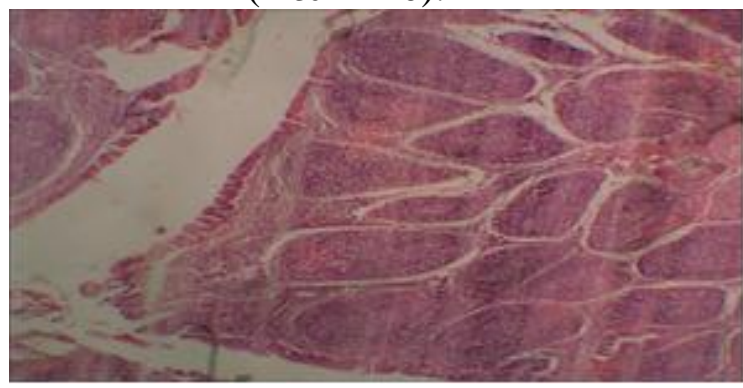

Fig. 8: T. S. in bursa fabrecieus for chick in $10 \mathrm{mg} \mathrm{L}$-car injection group. 
Ghonim, A. I. A.et al.

Transverse sections (T.S) in the thymus gland and spleen for hatched chicks at hatch

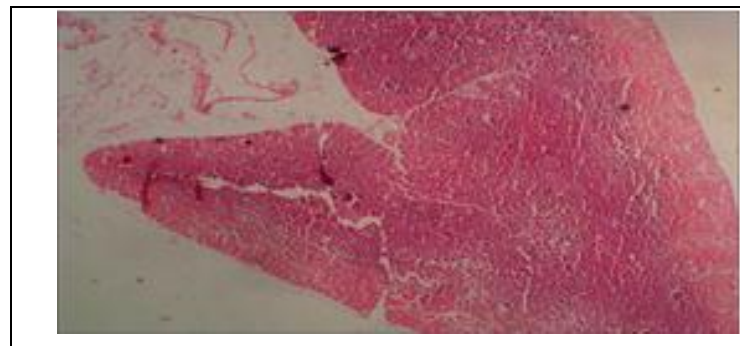

Fig. 9: T. S. in the thymus gland for chick in control group (H\&Ex 40).

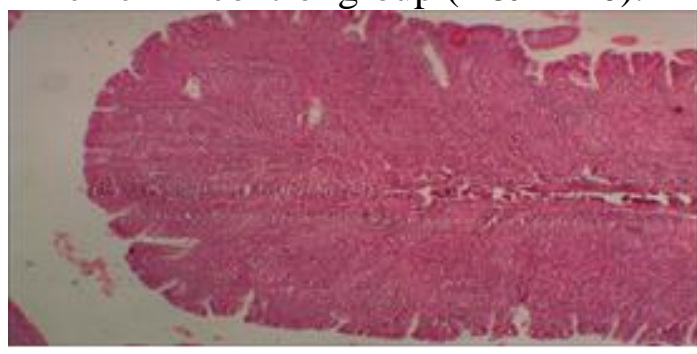

Fig. 11: T. S. in the thymus gland for chick in $8 \mathrm{mg} \mathrm{L}$-car injection group.

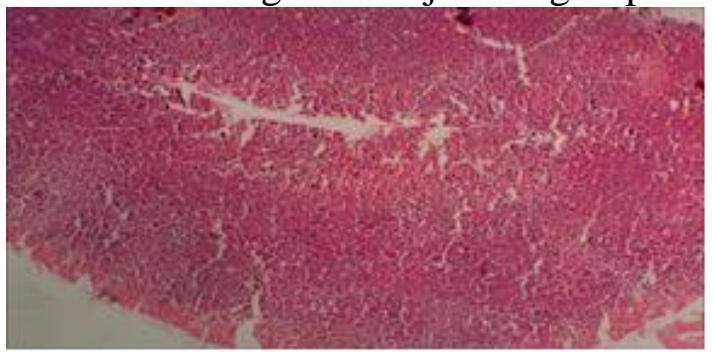

Fig. 13: T. S. in the spleen for chicks in control group (H\&Ex40).

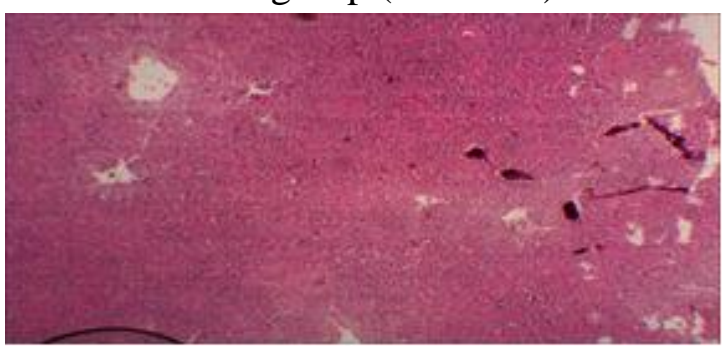

Fig. 15: T. S. in the spleen for chick in 8 mg L-car injection group (H\&Ex40).

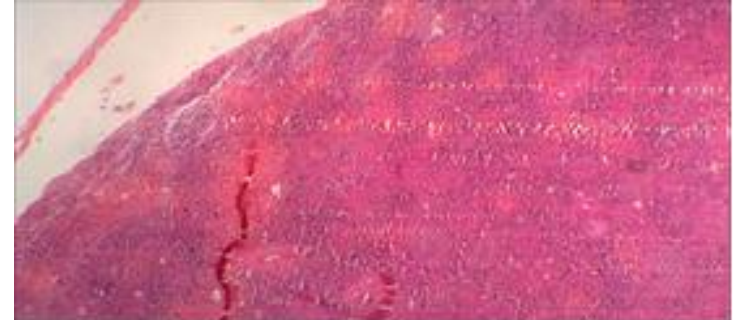

Fig. 10: T. S. in the thymus gland for chick in $6 \mathrm{mg} \mathrm{L}$-car injection group

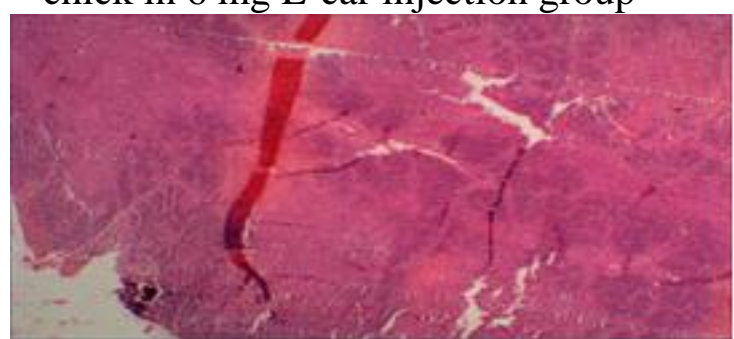

Fig. 12: T. S. in the thymus gland for chick in $10 \mathrm{mg}$ L-car injection group

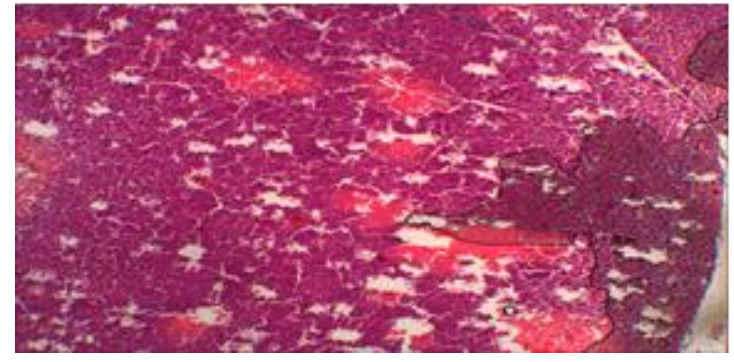

Fig. 14: T. S. in the spleen for chick in 6 mg L-car injection group

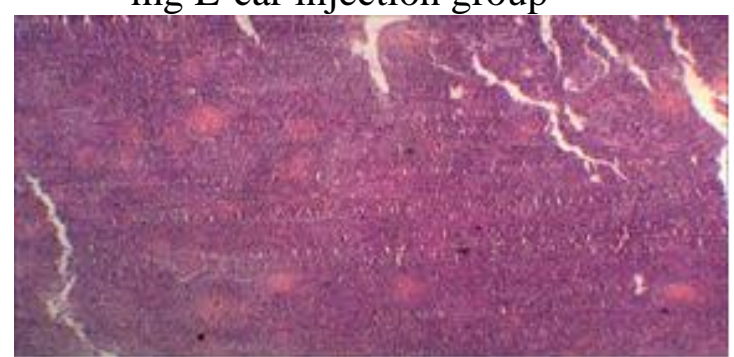

Fig.16:T. S. in the spleen for chick in 10 mg L-car injection group (H\&Ex40). 


\section{REFERENCES}

Abd El- Azeem, A. Nafisa; Sh. Abdo. Marwa; M. Madkour and I. ElWardany 2014. Physiological and Histological Responses of Broiler Chicks to in ovo Injection with Folic Acid or L-carnitine during Embryogenesis. Glob. Veterin., 13 (4) : 544-551.

Abdel-Fattah, S. A.; E.F. El-Daly and N. G. M. Ali 2014. Growth performance,immune response, serum metabolites an digestive enzyme activities of japanese quail fed supplemental L-carnitine. Global Ceterinaria, 12 (12):277-286.

Abdel-Fattah, S.A. and M. I. Shourrap 2012. Physiological effects of in ovo $L$ carnitine and embryonic thermal conditioning on pre and posthatch development of broiler chicks. $3^{\text {rd }}$ Mediterranean Poultry Summit and $6^{\text {th }}$ international Poultry conference, 26-29 Mar. 2012, Alex., Egypt.

Abd El-Moneim E. A.; I. El-Wardany ; A. M. Abu-Taleb ; Magda M. Wakwak ;T. A. Ebeid and A. A. Saleh 2020. Assessment of In Ovo Administration of Bifidobacterium bifidum and Bifidobacterium longum on Performance, Ileal Histomorphometry, Blood Hematological, and Biochemical Parameters of Broilers. Probiotics and Antimicrobial Proteins (2020) 12:439450.

Al-Daraji, H.J.; A.A. Al-Mashadani; W.E. Al-Hassani and H. A. Mirza 2012. Effect of in ovo injection with L-arginine on productive and physiological traits of Japanese quail. S. Afr. J. Sci. Vol.42 n2 pretoria Jan.
Abiola, S.S.; O.O Meshioye and M.A. Oyerinde, B.O. Bamgbose 2008. Effect of egg size on hatchability of broiler chicks. Arch. Zootech. S7, 8386.

Agarwal, A., S.A. Prabakaran and T. M. Said 2005. Pervention of oxidative stress injury to sperm. J. Androl. 26: 654-660.

Akter, S. H. ; M.Z. Khan ; M. R. Hahan ; M. R. Karim and M. R. Islam 2006. Histomorphological study of the lymphoid tissues of broiler chickens. Bangl. J. Vet. Med., 4: 8792.

Al-Murrani, W. K. 1978. Maternal effects on embryonic and postembryonic growth in poultry. Br. Poult. Sci. 19: 277-281.

Borum, P.R. 1983. Carnitine. Annu. Rev. Nutr. ( 3): 233-259.

Britton, K. E; V. C. Quinn; B. L. Brown andR. P. Edkins 1975. Astrategy for thyroid function tests. Brit. Med. J. 111 : 350-356.

Buyse, J.; G.P. Janssens and E. Decuypere 2001. The effect of dietary L-carnitine supplementation on the perfprmance, organ weights and circulating hormone and metabolite concentration of broiler chickens reared under a normal or low temperature schedule. Br. Poult. Sci.( 42):230-241.

Dooley, M., E.D. Peebles, W. Zhai, L. Mejia, C.D. Zumwalt and A. Corzo, 2011. Effects of Lcarnitine via in ovoinjection with or without Lcarnitine feed supplementation on broiler hatchability and posthatch performance. J. Applied Poult. Res., 20: 491-497. 
Ghonim, A. I. A.et al.

Doumas, B. T.; W. A.Watson and H. G. Biggs 1971. Albumin standerds and measurement of albumin with bromocresol green. Clin. Chim. Acta.( 31): 87-96.

Duncan, D.B. 1955. Multiple range and multiple F tests. Biometrics, 1:1-42.

El-Daly, F. Eman ; Nafisa A. Abd ElAzeem, I. El-Wardany, A.H. Abd ElGawad and A.E.A. Hemid 2014. Effect of Different Anti-Stress Feed Additives on Some Blood Metabolites and Lymphoid Organs Histology in Laying Japanese Quail. World Applied Sciences Journal 29 (12): 1574-1585.

Foye, O. T. , Z. Uni, and P. R. Ferket 2006. Effect of in ovo feeding egg white protein, beta-hydroxy-betamethylbutyrate, and carbohydrates on glycogen status and neonatal growth of turkeys. Poult. Sci. ( 85):1185-1192.

Gornal, A. G.; C. J. Bardawill and M. M. David 1949. Determination of serum proteins by means of the biuret reaction. J. Biol.chem.66- 177:751.

Helper, O. E. 1966. Manual of clinical laboratory methods. Thomas. SpringField, Illinois, USA.

Hodges, R.D. 1974. The Histology of the fowl. Academic Press, NY.

Keralapurath, M.M.; A. Corzo; R. Pulikanti; W. Zhai and E. D. Peebles 2010. Effects of in ovo injection of Lcarnitine on hatchability and subsequent broiler perfprmance and slaughter yield. Poult. Sci., 89 : 1497 1501.

Khan, M. Z. I., A. Masum, M. Z. I. khan, A. R. B. Aziz, M. Nasrin, M. N. H. Siddiqi and M. M. B. Ashad 2014. Histomorphology of the Lymphoid Tissues of Broiler Chickens in Kelantan, Malaysia. Sain Malaysiana, 43: 1175- 1179.
Koracevic,D.D ,G.Koracevic \& V, Csic, 2001. Method for the measurement of antioxidant activity in human fluids. J, clin. Pathol., 54 (5) : 356- 364.

Mast, J.; J. Buyse and B. M. Goddeeris 2000. Dietary L-carnitine supplementation increases antigenspecific immunoglobulin $G$ production in broiler chickens. Br. J. Nutr., 83: 161-166.

Ohta, Y; M.T. Kidd and T. Ishibashi 2001. Embryo growth and amino acid oncentration profiles of broiler breeder eggs, embryos, and chicks after in ovo administration of amino acids. Poult. Sci. (80):1430-1436.

Ohta, Y; N. Tsushima; K. Koide ; M.T. Kidd and T. Ishibashi11999. Effect of amino acid injection in broiler breeder eggs on embryonic growth and hatchability of chicks. Poult. Sci.(78):1493-1498.

Rabie, M.H.; F.S.A. Ismaail and A.A.S. Ahmed 2015. Effect of in ovo injection in broiler breeders and posthatch performance. Asian j. of Anim.and Veter. Advances., 10 (12): 875-884.

Rebouche, C.J. 1992. Carnitine function and requirements during the life cycle. FASEB J., 6: 3379-3386.

SAS Institute. 2004. SAS User's Guide: Statistics. Edition 9.1. SAS Institute Inc., Cary, NC.

Shafey, T.M.; H.A. Al-Batshan; A.N. Al-Owaimer ana K.A. Ai-Samawei 2010. Effects of in ovo administration of L-carnitine on hatchability performance,glycogen status and insulin-like growth factor-1 of broiler chickens. Brit. Poult. Sci., 51(1): 122131.

Salmanzadeh, M.; Y. Ebrahimnezhad and H.A. Shahryar 2013. The effect of in ovo injection of L-carnitine on 


\section{L-carnitine, In ovo, performance, Hatchability, Bronze turkey.}

hatching traits, growth performance, and carcass chraracteristics of turkey poults. Bull. Env. Pharmacol. Life. Sci., vol 2(11): 125-128.

Tietz, N. W.1986. Textbook of Clinical Chemistry. N. B. Saunder Co., London, Philadelphia, 18.1.

Weis, J.; H. Cyril; P. Gabriel; B. Baraňska; J.Bujko and L. Malíková
2011. Effect of the egg size on egg loses and hatchability of the Muscovy duck. Anim. Sci. and Biotech., 44 :354-356.

Zhai, W., S. Neuman, M.A. Latour and P.Y. Hester 2008. The Effect of in ovo njection of L-carnitine on hatchability of white leghorns. Poult. Sci., 87(3): 569-572.

\section{الملخص العربى}

\section{محاولة تحسين نسبة الفقس لبيض تفريخ الرومى البرونزى بتقنية حقن البيض بالـ كارنيتين

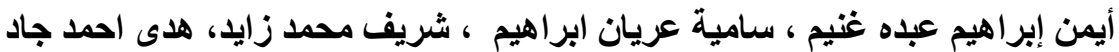

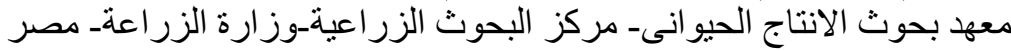

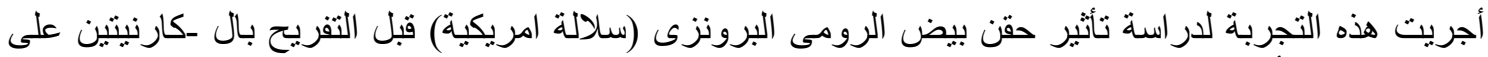

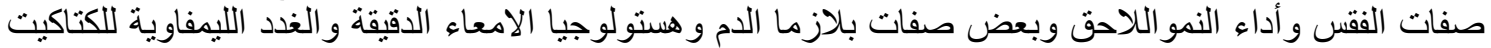

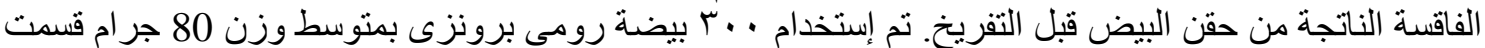

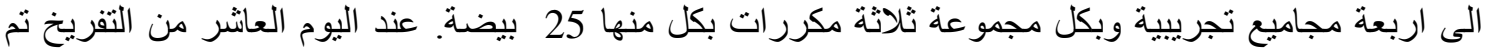

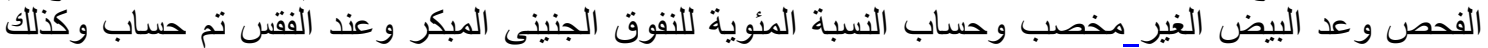

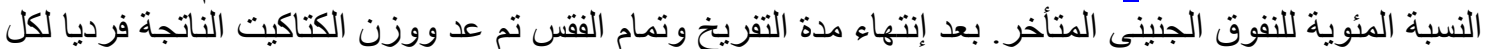

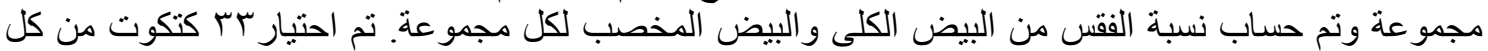

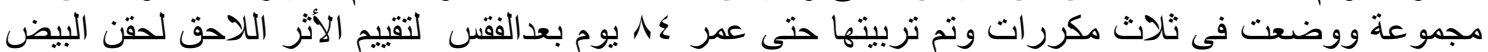

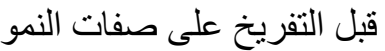

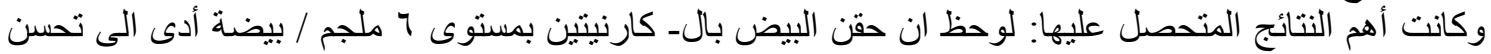

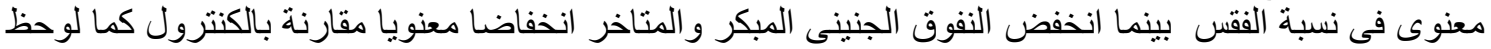

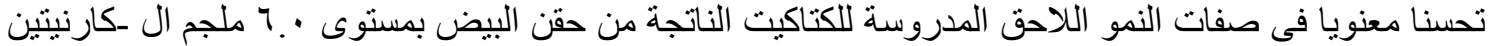

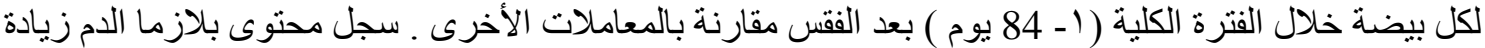

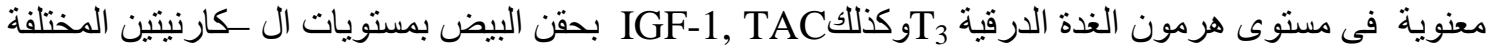

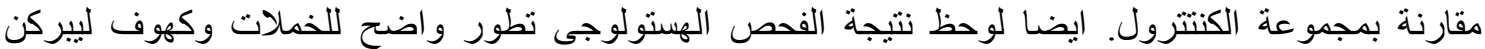

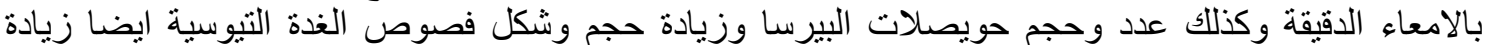

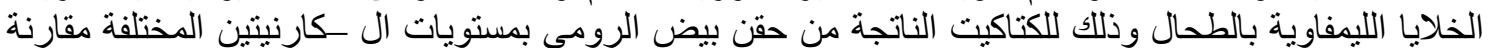

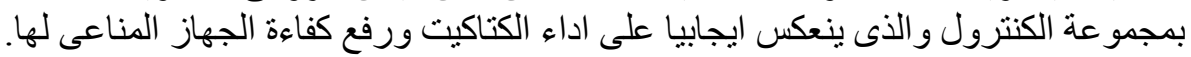

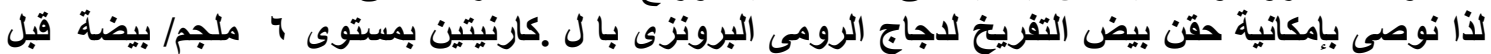
التفريخ كطريقة تقنية مفيدة لتحسين نسبة الفقس وتفليل النفوق الجنينى ورفع مناعة الكتئ الكتاكيت الفاقسة وتحسين أداء النمو اللاحق بعد الفقس. 